\title{
Morphological Characterization of High Grain Iron and Zinc Concentration Bio-fortified lentil (Lens culinaris Medikus subsp. culinaris) in Nepal
}

\begin{abstract}
Darai R ${ }^{1 *}$, Dhakal $\mathrm{KH}^{2}$, Sarker A ${ }^{3}$, Pandey $\mathbf{M P}^{2}$, Agrawal SK ${ }^{4}$ and Thapa DB $^{5}$

${ }^{1}$ Coordinator and Senior Scientist (S-4), Nepal Agricultural Research Council, Grain Legumes Research Program, Khajura, Nepalgunj, Nepal

${ }^{2}$ Assistant Professor and Professor, Faculty of Agriculture, Department of Genetics and Plant Breeding, Agriculture and Forestry University (AFU), Rampur, Chitwan, Nepal ${ }^{3}$ Regional Coordinator/Principal Food Legumes Breeder, South Asia and China Program (ICARDA), NASC

Complex, New Delhi, India

${ }^{4}$ Principal Scientist, International Center for Agricultural Research in the Dry Areas (ICARDA), India

${ }^{5}$ Senior Scientist and Chief, National Genetics and Plant Breeding Centre, NARC, NARI, Khumaltar, Nepal

*Corresponding author: Rajendra Darai, Coordinator and Senior Scientist (S-4), Nepal Agricultural Research Council, Grain Legumes Research Program, Khajura, Nepalgunj, Banke Lumbini Province, Nepal
\end{abstract}

Received: June 04, 2021; Accepted: July 01, 2021; Published: July 08, 2021

\begin{abstract}
Lentil (Lens culinaris Medikus subsp. culinaris) is the wonderful, most popular \& preferred food legume of Nepalese people and commonly grown in the rice and maize based cropping system. Morphological characters have been frequently used in order to know the diversity in germplasm collections. The main objectives of the study were to characterize the bio-fortified lentil accessions using morphological markers and select the DUS accession for using targeted the best utilization in hybridization program. Plant breeders can use these morphological variations to make decision regarding the choice for selecting superior genotypes for improvement or to be utilized as parents for the development of future cultivars through hybridization. Furthermore, important morphological markers like, plant type, foliage color, testa color, testa pattern and cotyledon colors can also be used for testing hybridity and keeping genetic purity at genetic level. The information obtained by the identification keys at seed and plant levels may be useful for discrimination and verification of varieties, hybridity testing and maintenance of genetic purity at genetic level during seed production and certification programme. Out of 25 lentil accessions, 18 accessions were observed as erect and compact growth habit, 22 accessions had green stem color, 21 accessions had dense leaf pubescence and dark foliage, 7 accessions had prominent tendril, 3 accessions had white blue veins flower and 4 accessions had large seeded accession.
\end{abstract} traits

Keywords: Lentil; Characterization; Morphological markers; Qualitative

\section{Introduction}

Lentil (Lens culinaris Medikus subsp. culinaris) is a diploid ( $2 \mathrm{x}$ $=2 \mathrm{n}=14$ chromosomes) autogamous annual species with a haploid genome size of an estimated 4063Mbp [1]. Lentil is the wonderful, most popular \& preferred food legume of Nepalese people and commonly grown in the rice and maize based cropping system. Globally, it is cultivated for its protein-rich grains in as many as 53 countries on 6.65 million ha area with annual production of 7.97 million tons with an average productivity around 1.19 ton/ha [2]. However, top ten countries, namely Canada, India, Turkey, Nepal, Australia, China, Iran, USA, Syria, and Ethiopia contribute about $95 \%$ of the global production. Its more than $85 \%$ lentil was produced in five specific regions including India, Nepal, and Bangladesh (32\%); western Canada (29\%); Turkey and northern Syria (18\%); Australia (4\%). In Nepal, lentil is the most important legumes which shares about $64 \%$ and $67 \%$ of the total legume area and production, respectively with productivity of around $1200 \mathrm{~kg} / \mathrm{ha}$ [3]. Swift cooking quality, tasty pink red cotyledons, high micronutrient contents and almost organic products make Nepalese lentil highly preferable to the lentil consumers and popular in the international market [4]. Bangladesh, Singapore, SriLanka, Germany, Korea, UK, Indonesia are the major export markets for Nepalese lentils [5]. Although, it is not a major crop but it is consumed for its high levels of protein, fibers, antioxidants and micronutrients including iron, zinc, selenium and vitamin (A and B complex), folate and $\beta$ carotene [6]. The crop has great significance in cereal-based cropping systems because of its nitrogen-fixing ability, early maturing and tolerance to drought. It is mainly grown in four province no. 2, 5, 7 and 1 and in top ten districts Dang, Rauthat, Kailali, Bardiaya, siraha, Bara, Banke, Nawalparasi, Saptari, Parsa which covers about $90 \%$ area. Lentil is a slender, softly pubescent, annual herbaceous plant which had considerable range of morphological variations among its germplasm. Considerable variations among the characters for use in breeding and selection programmes have been reported [7-10]. First recorded detailed morphological descriptions of lentil landraces and species from Asia [11]. Morphological markers like growth habit, stem color, leaf pubescence, leaflet sizes, foliage color, flower ground color, no. of flowers per peduncle, pod pigmentation, seed sizes, seed coat color, seed coat pattern and cotyledon color, lodging susceptibility, no. of nodules/plant, cold susceptibility etc are important for testing hybridity segregates and keeping genetic purity to be used in marker assisted selection. Targeted and more efficient utilization of germplasm by plant breeders can be achieved if the trait characteristics of accessions are known. In recent days, India has witnessed the emergence of large and' highly competitive variety development programs. However, morphological descriptors of many cultivars are imprecise. Any characters/traits of the plants are governed by oligogenes or polygenes, the character produced by oligogenes are generally made of one or few genes with large, easily detectable effects 
Table 1: Source of collection and country of origin of 25 lentil accessions.

\begin{tabular}{|c|c|c|c|c|}
\hline Accession Code no & Accessions & Pedigree & Types of materials & Source/Origin \\
\hline 1 & ILL-8006 & ILL5888 x ILL5782 & Breeding lines & Bangladesh \\
\hline 2 & RL-6 & ILL8008 x ILL5888 & Nepal cross & Nepal \\
\hline 3 & $\mathrm{RL}-12$ & Sindur $x$ Khajura-2 & Nepal cross & Nepal \\
\hline 4 & ILL-7715 & FLIP95-59L & Breeding lines & ICARDA \\
\hline 5 & ILL-7164 & PAK86591 & Breeding lines & ICARDA \\
\hline 6 & ILL-3490 & & Breeding lines & ICARDA \\
\hline 7 & Khajura-2 (PL639) & L9-12xType 8 & Released & GPPUAT, Pantanagar \\
\hline 8 & Simal (LG7) & Land race from India & Released & India \\
\hline 9 & Shital (ILL2580) & L1278 & Released & ICARDA/India \\
\hline 10 & Sagun (ILL6829) & ILL4907(Pakistan)x ILL4605 (Argentine) & Released & ICARDA \\
\hline 11 & HUL-57 & Mutant of HUL1 & Cultivar & BHU, Banaras, India \\
\hline 12 & LG-12 & Local landrace from India & Cultivar & India \\
\hline 13 & $\mathrm{PL}-4$ & UPL175x(PL184xP228) & Cultivar & GPPUAT, Pantanagar \\
\hline 14 & RL-11 & - & Nepal cross & Nepal \\
\hline 15 & RL-4 (Khajura-3) & ILL6037xILL8007 & Released & Nepal \\
\hline 16 & ILL-2712 & - & Breeding lines & ICARDA \\
\hline 17 & Black Masuro & Local landrace from Ramechap, Nepal & Released & Nepal \\
\hline 18 & $\mathrm{RL}-79$ & $99595-2-1$ & Nepal cross & Nepal \\
\hline 19 & ILL-6467 & ILL4605xILL2582 & Breeding lines & ICARDA \\
\hline 20 & ILL-7979 & FLIP1996-47L & Breeding lines & ICARDA \\
\hline 21 & ILL-6819 & FLIP88-461 & Breeding lines & ICARDA \\
\hline 22 & ILL-7723 (Khajura-4) & Sel89503 & Released & ICARDA/Pakistan \\
\hline 25 & RL-49 & NR9901-1-17 & Nepal cross & Nepal \\
\hline
\end{tabular}

which causes show distinct classes and are known as the qualitative characters or oligogenic traits such as stem pigmentation color, flower color, cotyledon color etc. Likely in polygenes character governed by several genes with small individual effects usually additive which are highly influenced by the environments and they don't show any clear cut classes called as quantitative characters or plygenic traits like plant height, days to flower, days to maturity, grain yield, hundred seed weight etc. Morphological characters have been frequently used in order to know the diversity in germplasm collections [10,12-20]. Considering all these facts, the main objectives of the study was to characterize the bio-fortified lentil accessions using morphological markers and select the DUS accession for using targeted the best utilization in hybridization program.

\section{Materials and Methods}

The present study was conducted with a comprised of 25 different lentil accessions, which has a high concentration of grain Iron and Zinc, among which six lines were released varieties, 7 advanced breeding lines, 5 cultivars and five Nepalese cross lines (Table 1). Sources of accessions were from the International Center for Agricultural Research in Dry Areas (ICARDA), Shuttle breeding and SAARC trial (Bangladesh Agricultural Research Institute, Indian Institute of Pulses Research) and National Agriculture Genetic Resources Centre
(Gene Bank), Nepal. These accessions were originated from SAARC countries -14 lines (Nepal-7, India-6, Bangladesh-1) and 11 ICARDA breeding lines were used for this study. A total of 25 lentil accessions were evaluated in winter season of 2016/17 in alpha lattice design (5x5) with three-replication. The unit plot size consisted of six rows of $2 \mathrm{~m}$ length with row to row and plant to plant spacing of $25 \mathrm{~cm}$ and continues, respectively. The recommended packages of practice were strictly followed for raising a good crop. Accessions were evaluated for 18 morphological descriptors viz. growth habit, stem color, leaf pubescence, leaflet sizes, foliage color, tendril length, flower ground color, no. of flowers per peduncle, pod pigmentation, seed sizes, seed coat color, seed coat pattern, cotyledon color, lodging susceptibility, no. of nodules/plant, cold susceptibility score, stemphylium blight score. These characters were recorded as per descriptors of IBPGR. The observations were recorded in five plants in each plot at specified stages of crop growth period when the characters under study had full of expression. Traits like Growth habit, stem color, leaf pubescence, leaflet sizes, foliage color, flower ground color, flowers per peduncle were recorded during the flower bud stage while disease scoring was done at pod formation stage. Other observations like pod pigmentation, seed sizes, seed coat color, seed coat pattern, cotyledon color were observed visually after harvesting the seeds at maturity. 


\section{Results}

A total of eighteen different qualitative and quantitative traits of 25 lentil accessions were studied which are important morphological markers for keeping distinguish uniform and stable lines. Adequate amount of variation was present among the 25 accessions for eighteen important traits under study. The 25 accessions under study were classified into discrete groups under 18 major categories representing 14 qualitative characters viz. growth habit, stem color, leaf pubescence, leaflet sizes, foliage color, flower ground color, no. of flowers per peduncle, pod pigmentation, seed sizes, seed coat color, seed coat pattern and cotyledon color and 4 quantitative characters viz. lodging susceptibility, no. of nodules/plant, Inactive nodules, cold susceptibility (Table 2). On the basis of present preliminary characterization, these genotypes were grouped into different categories and may be used as a reference accession. They were classified into separate groups under each character as shown in Table 3.1 and Table 3.2 .

\section{Growth habit}

On the basis of IBPGR descriptors for DUS testing in lentil, accessions have been categorized as Erect and Compact and semispreading based on the growth habit. Out of 25 accessions; 18 accessions were fall in erect and compact group and 7 accessions were semi-spreading type.

\section{Stem color}

Stem color is an important morphological character, varied from green to purple. Green stem color was found in three accessions and the rest 22 accessions were with purple stem. Most of the accessions originated from ICARDA were found with purple stem while the green stem color of other accessions was originated from India and Nepal.

Table 2: Qualitative and Quantitative traits used in the characterization of lentil accessions from 'Lentil Descriptors' by IBPGR (1985).

\begin{tabular}{|c|c|}
\hline Traits & Description \\
\hline Growth habit & Qualitative \\
\hline Stem color & Qualitative \\
\hline Leaf pubescence & Qualitative \\
\hline Leaflet sizes & Qualitative \\
\hline Foliage color & Qualitative \\
\hline Tendril length & Qualitative \\
\hline Flower ground color & Qualitative \\
\hline No. of flowers per peduncle & Qualitative \\
\hline Pod pigmentation & Qualitative \\
\hline Seed sizes & Qualitative \\
\hline Seed coat color & Qualitative \\
\hline Seed coat pattern & Qualitative \\
\hline Cotyledon color & Qualitative \\
\hline Lodging susceptibility & Quantitative \\
\hline No. of nodules /plant & Quantitative \\
\hline Inactive nodules & Quantitative \\
\hline Cold susceptibility & Quantitative \\
\hline Stemphlium blight & Qualitative \\
\hline
\end{tabular}

\section{Leaf pubescence}

Leaf pubescence is also typical character containing in the lentil leaves which has distinguished the varietal characters. In general, it is categorized into three group's i.e. dense pubescence, slight pubescence and absent pubescence. Dense pubescence was found in 21 accessions likely slight pubescence was found in three accessions and no pubescence or glabrous was found in 1 accession.

\section{Leaflet sizes}

Leaflet sizes are another important key morphological character; it is generally categorized into three groups' small, medium and large leaflets sizes. Most of the lentil accessions were found small leaflets mainly originated from ICARDA. 13 different accessions had found small leaflets, while 9 accessions had large leaflet sizes and three accessions were medium leaflets sizes out of 25 accessions.

\section{Foliage color}

Among the morphological traits observed during field evaluation, the foliage colour may be considered as distinguishing, stable and uniform trait for DUS characterization. Lentil accessions have been categorized as light green and dark green and accessions under study contains both two form of foliage color. Dark green foliage was more common among the accessions under study, as 21 accessions had dark green foliage. Only four accessions observed with light green foliage type.

\section{Tendril lengths}

During crop growth and at maturity tendril keeps the plants intermingled and the canopy upright. This allows less seed loss in mechanical harvest. Depending upon the tendril lengths it may be prominent with long tendril or rudimentary with short or no tendril. Prominent tendril was found in 7 accessions and rudimentary with 18 accessions.

\section{Flower color}

Flower colors are the most important morphological traits which helps to distinguish, uniform and stable traits of any accessions. In general, there are broadly two groups of flower color pertaining in lentil i.e. blue and white with blue veins. In our study, white with blue veins flowers were observed in 3 accessions only while blue flowers which are governed by one gene were found in 22 accessions. Basically this trait is very important trait for testing hybridity segregates in crossing program and a key trait to keeping varietal purity at final level of seed production.

\section{Number of flowers per peduncle}

Number of flowers per peduncle is also a morphological trait which helps to distinguish the variety in minute level. It is categorized into two groups i.e. two flowers per peduncle and three flowers per peduncle. In our study, majority of the accessions i.e. 17 accessions had two flowers per peduncle while three flowers per peduncle was found in eight accessions.

\section{Pod pigmentation}

In general, there are two types of pod pigmentation i.e. absent or present. Pod pigmentation observation were observed during the well matured pods or harvesting stage. In our study, all accessions had absent any type of pod pigmentation. 
Table 3.1: Morphological Characterization of lentil accessions based on qualitative traits as per prescribed in IBPGR.

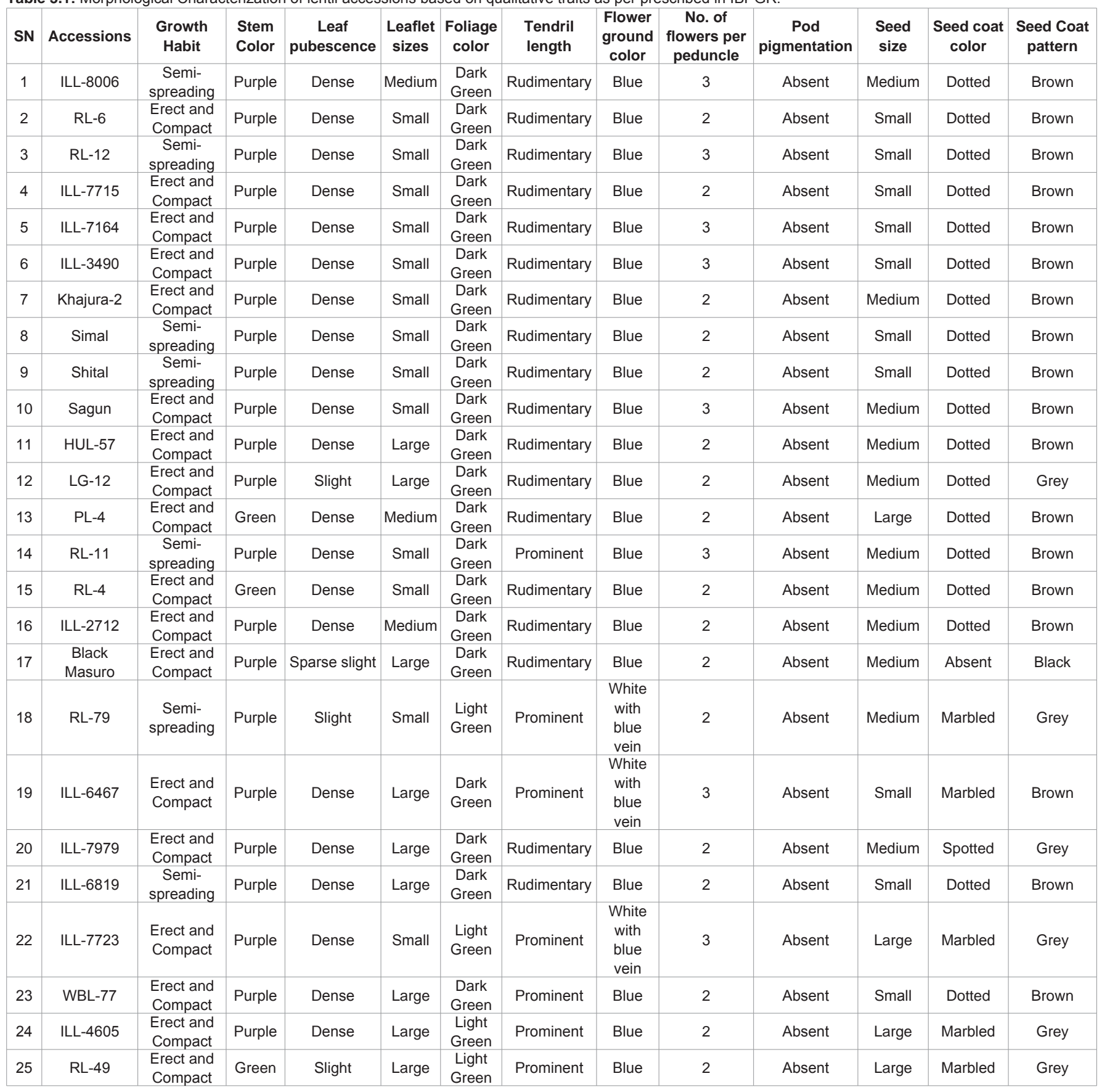

\section{Seed sizes}

Seed sizes are broadly classified into three group i.e. small, medium and large seeded lentil. In our study, 10 accessions were grouped into small seed size, 11 lentil accessions had medium seed sizes and 4 accessions in large seed sizes. Lentil seed sizes are grouped into two types: macrosperma, or large seeded varieties and microsperma, or small seeded varieties. Macrosperma is found mainly in the Mediterranean region and the New World (seed size ranging from 6 to $9 \mathrm{~mm}$ in diameter and yellow cotyledons with little or no pigmentation) and microsperma (2 to $6 \mathrm{~mm}$ with red orange or yellow cotyledons) is found on the Indian subcontinent, Near East and East Africa, respectively, are known [32,33]. The first one includes the Chilean or yellow cotyledon types while the latter includes the small seeded Persian or red cotyledon lentils [34].

\section{Seed coat colour, seed coat pattern and cotyledon color}

Expression of seed characters like, seed coat color, seed coat pattern and cotyledon color are uniform and stable. Therefore, these traits are better criteria for distinguishing the lentil accessions. Three classes were formed on the basis of seed coat color i.e., grey, brown and black. Among 25 accessions under study 18 accessions had brown seed coat color, 6 accessions had grey seed coat color and only single local collection observed with black color seed coat. On the basis of 
Table 3.2: Morphological Characterization of lentil accessions based on qualitative traits as per prescribed in IBPGR.

\begin{tabular}{|c|c|c|c|c|c|c|c|}
\hline Entry & Accessions & Cotyledon color & $\begin{array}{l}\text { Lodging } \\
\text { susceptibility }\end{array}$ & $\begin{array}{l}\text { No. of Nodules I } \\
\text { plant }\end{array}$ & $\begin{array}{l}\text { Inactive } \\
\text { Nodules }\end{array}$ & $\begin{array}{c}\text { Cold susceptibility (1-9 } \\
\text { scale) }\end{array}$ & $\begin{array}{c}\text { Stemphylium blight (1-9 } \\
\text { scale) }\end{array}$ \\
\hline 1 & ILL-8006 & Red & High & 10.5 & 4 & 5 & 3 \\
\hline 3 & RL-12 & Red & High & 10 & 3 & 5 & 4 \\
\hline 4 & ILL-7715 & Red & High & 19 & 4.5 & 7 & 3 \\
\hline 6 & ILL-3490 & Red & High & 13 & 3.5 & 5 & 3 \\
\hline 7 & Khajura-2 & Red & High & 20.5 & 4.5 & 5 & 3 \\
\hline 8 & Simal & Red & Medium & 3.5 & 2 & 7 & 3 \\
\hline 9 & Shital & Red & High & 16 & 4.5 & 5 & 7 \\
\hline 10 & Sagun & Red & High & 21.5 & 7.5 & 5 & 1 \\
\hline 12 & LG-12 & Red & High & 24.5 & 7.5 & 1 & 3 \\
\hline 13 & $\mathrm{PL}-4$ & Red & High & 17 & 7 & 5 & 3 \\
\hline 14 & $\mathrm{RL}-11$ & Red & High & 11 & 4 & 1 & 3 \\
\hline 15 & $\mathrm{RL}-4$ & Red & High & 21.5 & 7.5 & 5 & 3 \\
\hline 16 & ILL-2712 & Red & High & 17.5 & 4.5 & 1 & 3 \\
\hline 17 & Black Masuro & Red & High & 12.5 & 4.5 & 7 & 1 \\
\hline 18 & RL-79 & Red & High & 11.5 & 4 & 1 & 1 \\
\hline 19 & ILL-6467 & Red & High & 15 & 5 & 1 & 1 \\
\hline 20 & ILL-7979 & Red & High & 15 & 6 & 1 & 1 \\
\hline 21 & ILL-6819 & Red & High & 27 & 9.5 & 1 & 3 \\
\hline 22 & ILL-7723 & Red & Medium & 16.5 & 6 & 1 & 3 \\
\hline 24 & ILL-4605 & Red & High & 17 & 5 & 1 & 2 \\
\hline 25 & RL-49 & Red & High & 22 & 6.5 & 1 & 3 \\
\hline
\end{tabular}

seed coat pattern, four types of classes were formed based on spotted, dotted, marbled and absent. Out of 25 accessions, 19 accessions had dotted, five accessions had marbled, 1 accession spotted and 1 accession absent.

\section{Cotyledon color}

Visual assessment for cotyledon color was done one month after harvesting the seeds and can be categorized in three different classes as per IBPGR DUS guidelines i.e. Red, Yellow, Green, Black. Genotypes under study were classified into two categories i.e. yellow, and red. Almost all genotypes had found red color cotyledons.

\section{Number of nodules per plant}

Number of nodules per plant determines the capacity of biological nitrogen fixation by the lentil variety in the soil. It can be assumed that higher the number of nodules will have more nitrogen fixation which supply to the plants itself and provide more yield and also high protein content in the seed. Generally, there are categorized in three groups of nodules per plant i.e. very high, fair and poor. In our study, 8 accessions had the very high nodules per plant, 16 accessions had fair nodules per plant and 1 accession had poor nodules per plant.

\section{Stemphylium blight disease}

Lentil stemphylium blight is one of the major foliar diseases which cause substantial yield losses in lentil. In Nepal it was first reported during 1993. In Bangladesh and India estimated yield losses of $62 \%$ (Bakr 1991, Erksine and Sarker 1997). Nepalgunj is a hot spot for lentil stemphylium and the symptoms of stemphylium are visible on all plant parts. Hence, stemphylium scoring of accessions under study were done at field level and on the basis of stemphylium disease score accessions on a 1-9 scale under study were classified into four groups i.e. highly resistant, resistant, moderately resistant and moderately susceptible. Disease score was recorded before flowering and after flowering as followed by the Chen, 2007. Highly resistant group consisted of 6 accessions, 17 accessions were resistant out of 25 , and rest 1 accession was moderately resistant and 1 accession showed moderately susceptibility for stemphylium blight.

\section{Fusarium wilt disease}

Likewise, fusarium wilt was also serious disease in low land growing lentils where it is prevailing soil moisture stress. Based on the scale disease (1-9 score) contrary same as stemphylium blight. In our study, 4 accessions were found highly resistant to fusarium wilt disease, 16 accessions were resistant and 5 accessions were moderately resistant.

\section{Lodging susceptibility}

Lodging susceptibility is in fact quantitative trait that determined 
Table 4: Classification of 25 lentil accessions into distinct groups based on qualitative characters.

\begin{tabular}{|c|c|c|c|}
\hline Traits & & Name of accessions & $\begin{array}{c}\text { No. of } \\
\text { Accessions }\end{array}$ \\
\hline \multirow{4}{*}{ Stemphylium blight } & 1 (No infection) & Sagun, Black Masuro, RL-79, ILL-6467, ILL-7979, ILL-4605 & 6 \\
\hline & 3(Resistant) & $\begin{array}{c}\text { ILL-2712, ILL-6819, ILL-7723, ILL-8006, ILL-7715, ILL-7164, ILL-3490, Khajura-2, Simal, } \\
\text { HUL-57, LG-12, PL-4, RL-11, RL-4, WBL-77, RL-49, RL-12 }\end{array}$ & 17 \\
\hline & $\begin{array}{l}\text { 5(Moderately } \\
\text { Resistant) }\end{array}$ & $\mathrm{RL}-6$ & 1 \\
\hline & $\begin{array}{l}\text { 7(Moderately } \\
\text { Susceptible) }\end{array}$ & Shital & 1 \\
\hline \multirow{3}{*}{ Fusarium wilt } & 1 (No infection) & LG-12, Black Masuro, ILL-6467, WBL-77 & 4 \\
\hline & 3(Resistant) & $\begin{array}{c}\text { RL-6, RL-12, ILL-7715, ILL-7164, Shital, Sagun, HUL-57, PL-4, RL-11, RL-4, RL-79, ILL- } \\
\text { 7979, ILL-6819, ILL-7723, ILL-4605, RL-49 }\end{array}$ & 16 \\
\hline & $\begin{array}{l}\text { 5(Moderately } \\
\text { Resistant) }\end{array}$ & ILL-8006, ILL-3490, Khajura-2, Simal, ILL-2712 & 5 \\
\hline \multirow{2}{*}{ Growth habit } & Erect and Compact & $\begin{array}{l}\text { RL-6, ILL-7715, ILL-7164, ILL-3490, Khajura-2, Sagun, HUL-57, LG-12, PL-4, RL-4, ILL- } \\
\text { 2712, Black Masuro, ILL-6467, ILL-7979, ILL-7723, WBL-77, ILL-4605, RL-49 }\end{array}$ & 18 \\
\hline & Semi-spreading & ILL-8006, RL-12, Simal, Shital, RL-11, RL-79, ILL-6819 & 7 \\
\hline \multirow[b]{2}{*}{ Stem color } & Green & PL-4, RL-4, RL-49 & 3 \\
\hline & Purple & $\begin{array}{c}\text { ILL-8006, RL-6, RL-12, ILL-7715, ILL-7164, ILL-3490, Khajura-2, Simal, Shital, Sagun, HUL- } \\
\text { 57, LG-12, RL-11, ILL-2712, Black Masuro, RL-79, ILL-6467, ILL-7979, ILL-6819, ILL-7723, } \\
\text { WBL-77, ILL-4605 }\end{array}$ & 22 \\
\hline \multirow{3}{*}{ Leaf pubescence } & Absent & Black Masuro & 1 \\
\hline & Slight & LG-12, RL-79, RL-49 & 3 \\
\hline & Dense & $\begin{array}{l}\text { ILL-8006, RL-6, RL-12, ILL-7715, ILL-7164, ILL-3490, Khajura-2, Simal, Shital, Sagun, } \\
\text { HUL-57, PL-4, RL-11, RL-4, ILL-2712, ILL-6467, ILL-7979, ILL-6819, ILL-7723, WBL-77, } \\
\text { ILL-4605 }\end{array}$ & 21 \\
\hline \multirow{3}{*}{ Leaflet sizes } & Small & $\begin{array}{l}\text { RL-6, RL-12, ILL-7715, ILL-7164, ILL-3490, Khajura-2, Simal, Shital, Sagun, RL-11, RL-4, } \\
\text { RL-79, ILL-7723 }\end{array}$ & 13 \\
\hline & Medium & ILL-8006, PL-4, ILL-2712 & 3 \\
\hline & Large & HUL-57, LG-12, Black Masuro, ILL-6467, ILL-7979, ILL-6819, WBL-77, ILL-4605, RL-49 & 9 \\
\hline \multirow[t]{2}{*}{ Foliage color } & Dark Green & $\begin{array}{l}\text { ILL-8006, RL-6, RL-12, ILL-7715, ILL-7164, ILL-3490, Khajura-2, Simal, Shital, Sagun, } \\
\text { HUL-57, LG-12, PL-4, RL-11, RL-4, ILL-2712, Black Masuro, ILL-6467, ILL-7979, ILL-6819, } \\
\text { WBL-77 }\end{array}$ & 21 \\
\hline & Light Green & RL-79, ILL-7723, ILL-4605, RL-49 & 4 \\
\hline \multirow{2}{*}{ Tendril length } & Rudimentary & $\begin{array}{l}\text { ILL-7979, ILL-6819, ILL-8006, RL-6, RL-12, ILL-7715, ILL-7164, ILL-3490, Khajura-2, Simal, } \\
\text { Shital, Sagun, HUL-57, LG-12, PL-4, RL-4,ILL-2712, Black Masuro }\end{array}$ & 18 \\
\hline & Prominenet & RL-11, RL-79, ILL-6467, ILL-7723, WBL-77, ILL-4605, RL-49 & 7 \\
\hline \multirow[t]{2}{*}{ Flower color } & Blue(One gene) & $\begin{array}{c}\text { ILL-8006, RL-6, RL-12, ILL-7715, ILL-7164, ILL-3490, Khajura-2, Simal, Shital, Sagun, } \\
\text { HUL-57, LG-12, PL-4, RL-11, RL-4, ILL-2712, Black Masuro, ILL-7979, ILL-6819, WBL-77, } \\
\text { ILL-4605, RL-49 }\end{array}$ & 22 \\
\hline & White with blue veins & RL-79, ILL-7723, ILL-6467 & 3 \\
\hline \multirow{2}{*}{$\begin{array}{l}\text { No. of flowers } \\
\text { per peduncle }\end{array}$} & $\begin{array}{l}2 \text { flowers per } \\
\text { peduncle }\end{array}$ & $\begin{array}{l}\text { RL-6, ILL-7715, Khajura-2, Simal, Shital, HUL-57, LG-12, PL-4, RL-4, ILL-2712, Black } \\
\text { Masuro, RL-79, ILL-7979, ILL-6819, WBL-77, ILL-4605, RL-49 }\end{array}$ & 17 \\
\hline & $\begin{array}{l}3 \text { flowers per } \\
\text { peduncle }\end{array}$ & ILL-8006, RL-12, ILL-7164, ILL-3490, Sagun, RL-11, ILL-6467, ILL-7723 & 8 \\
\hline Pod pigmentation & Absent & $\begin{array}{l}\text { ILL-8006, RL-6, RL-12, ILL-7715, ILL-7164 ILL-3490, Khajura-2, Simal, Shital, Sagun, } \\
\text { HUL-57, LG-12, PL-4, RL-11, RL-4,ILL-2712, Black Masuro, RL-79, ILL-6467, ILL-7979, } \\
\text { ILL-6819, ILL-7723, WBL-77, ILL-4605, RL-49 }\end{array}$ & 25 \\
\hline \multirow{3}{*}{$\begin{array}{l}\text { Seed } \\
\text { sizes }\end{array}$} & Small & RL-6, RL-12, ILL-7715, ILL-7164, ILL-3490, Simal, Shital, ILL-6467, ILL-6819, WBL-77 & 10 \\
\hline & Medium & $\begin{array}{l}\text { ILL-8006, Khajura-2, Sagun, HUL-57, LG-12,RL-11, RL-4, ILL-2712, Black Masuro, RL-79, } \\
\text { ILL-7979 }\end{array}$ & 11 \\
\hline & Large & PL-4, ILL-7723, ILL-4605, RL-49 & 4 \\
\hline \multirow{4}{*}{ Seed coat pattern } & Spotted & ILL 7979 & 1 \\
\hline & Dotted & $\begin{array}{l}\text { ILL-8006, RL-6, RL-12, ILL-7715, ILL-7164, ILL-3490, Khajura-2, Simal, Shital, Sagun, } \\
\text { HUL-57, LG-12, PL-4, RL-11, RL-4, ILL-2712, ILL-6819, WBL-77, RL-79 }\end{array}$ & 19 \\
\hline & Marbled & RL-79, ILL-6467, ILL-7723, ILL-4605, RL-49 & 5 \\
\hline & Absent & Black Masuro & 1 \\
\hline \multirow{3}{*}{ Seed Coat color } & Grey & LG-12, RL-79, ILL-7979, ILL-7723, ILL-4605, RL-49 & 6 \\
\hline & Brown & $\begin{array}{c}\text { ILL-8006, RL-6, RL-12, ILL-7715, ILL-7164, ILL-3490, Khajura-2, Simal, Shital, Sagun, HUL- } \\
\text { 57, PL-4, RL-11, RL-4, ILL-2712, ILL-6467, ILL-6819, WBL-77 }\end{array}$ & 18 \\
\hline & Black & Black Masuro & 1 \\
\hline
\end{tabular}




\begin{tabular}{|c|c|c|c|}
\hline $\begin{array}{l}\text { Cotyledon color (Red, } \\
\text { Yellow, Green, Black) }\end{array}$ & Red & $\begin{array}{l}\text { ILL-8006, RL-6, RL-12, ILL-7715, ILL-7164 ILL-3490, Khajura-2, Simal, Shital, Sagun, } \\
\text { HUL-57, LG-12, PL-4, RL-11, RL-4,ILL-2712, Black Masuro, RL-79, ILL-6467, ILL-7979, } \\
\text { ILL-6819, ILL-7723, WBL-77, ILL-4605, RL-49 }\end{array}$ & 25 \\
\hline \multirow{4}{*}{ Lodging susceptibility } & None & & \\
\hline & Low & & \\
\hline & Medium & Simal, ILL-7723, WBL-77 & 3 \\
\hline & High & $\begin{array}{l}\text { ILL-8006, RL-6, RL-12, ILL-7715, ILL-7164, ILL-3490, Khajura-2, Shital, Sagun, HUL-57, } \\
\text { LG-12, PL-4, RL-11, RL-4, ILL-2712, Black Masuro, RL-79, ILL-6467, ILL-7979, ILL-6819, } \\
\text { ILL-4605, RL-49 }\end{array}$ & 22 \\
\hline \multirow{3}{*}{ No. of Nodules /plant } & Very good(>20-30) & ILL-6819, LG-12, RL-49, RL-6, Sagun, RL-4, ILL-7164, Khajura-2 & 8 \\
\hline & Fair(10-20) & $\begin{array}{l}\text { ILL-7715, ILL-2712, PL-4, ILL-4605, ILL-7723, Shital, ILL-6467, ILL-7979, ILL-3490, Black } \\
\text { Masuro, RL-79, RL-11, ILL-8006, HUL-57, WBL-77, RL-12 }\end{array}$ & 16 \\
\hline & Poor $(<10)$ & Simal & 1 \\
\hline \multirow{3}{*}{$\begin{array}{l}\text { Cold susceptibility } \\
\qquad(1-9 \text { scale })\end{array}$} & Resistant & $\begin{array}{l}\text { HUL-57, LG-12, RL-11, ILL-2712, RL-79, ILL-6467, ILL-7979, ILL-6819, ILL-7723, WBL-77, } \\
\text { ILL-4605, RL-49 }\end{array}$ & 12 \\
\hline & & & \\
\hline & Susceptible & ILL-7715,Simal, Black Masuro & 3 \\
\hline
\end{tabular}

by the environmental influences, planting time and soil fertility. This is quantified into three group i.e. low, medium and high susceptibility. Most of the accessions i.e. 22 accessions were high lodging susceptibility and three accessions had medium susceptibility.

\section{Cold susceptibility}

Cold susceptibility is also showed the symptoms during the seedling stage of cold climate which causes turns into reddish brown plant foliage observed in the field. In fact, reddish foliage means the symptoms of phosphorus deficiency particularly seen in those areas where more calcium carbonate adheres in the soil. In mid and high hills can also be encountered in the lentil field. Cold susceptibility is categorized in three classes, in our study, 12 accessions were found resistant to cold climate, 10 accessions were moderately resistant and three accessions were found susceptible to the cold climate.

\section{Discussion}

Growth habit supports the observations of [21], and [22]. This trait is monogenically governed with dominant expression of the tall erect plant habit [23]. Erect and spreading plant types were extreme expressions for this trait and these are more stable but semi-spreading expression may be altered with environmental fluctuations.

It is reported that based on the leaf pubescences, any accession can be identified either it is insect resistant or susceptible. Sometimes its pubescence works as the barrier to direct invade the crops.

On the basis of results obtained, it could be emphasized that morphological characters play a very important role and they do contribute towards genotype divergence in lentil. Light green color foliage turns yellow during maturity and leaves drop down during crop maturation. In contrast, dark green foliage persist for long and stay green during advanced stage of crop growth and resulted in high seed yield with fully matured seed. Stay green character of dark green foliage is desirable and genotypes with dark green foliage should be developed for high yield potential. Similar observations were also reported by [24]. It was reported that foliage color is controlled by single gene with dominance of dark green foliage over light green foliage [25].
It can be assumed that the higher the number of flowers per peduncle means higher the numbers of pod setting and finally produces more yield than two flowers bearer. Testa colour and testa mottling are found to be the most stable and uniform traits for certification of genetic purity of genotypes at four level as their expressions are least influenced by environment. Hence, these two traits in combination can be utilized to characterize the lentil accessions.

Cotyledon colour was controlled by single gene hence; trait is less influenced by the environment [26-29]. Therefore, it can be utilized for distinguishing the lentil genotypes. The intensity of cotyledon colour is affected with storage condition and time so; this trait may be useful only for varietal protection before entering into active seed multiplication chain. Cotyledon with red colour in lentil is preferred in Bangladesh, India, Nepal and other countries of Ethiopia, Eritrea, Sudan, Egypt, Turkey, Syria, etc. Likely yellow cotyledon lentil is preferred by the consumers of North Africa, Central Asia and Caucasus countries. Therefore, cotyledon colour might be a valuable trait for breeding purpose because of the consumers' preferences and its value chain in the international market.

It is said that in Root rot complex of lentil the main pathogens associated with plant mortality were Fusarium oxysporum f.sp. Lentis (62.0\%), Rhizoctonia bataticola (25.2\%) and Sclerotium rolfsii (9.8\%) in India [30]. Screening of lentil breeding lines for resistance to fusarium wilt found that yield losses can range from 25-95\% depending on the variety [31]. It might be both soil and seed borne pathogen. At seedling stage, sudden drooping of the leaves followed by the leaves drying and the eventual death of the seedling. At reproductive stage drooping and wilting of the uppermost leaflets and finally become completely yellow and die.

\section{Conclusion}

Plant breeders can use these morphological variations to make decision regarding the choice for selecting superior genotypes for improvement or to be utilized as parents for the development of future cultivars through hybridization. Furthermore, important morphological markers like, plant type, foliage color, testa color, testa pattern and cotyledon colors can also be used for testing hybridity 
and keeping genetic purity at genetic level. The information obtained by the identification keys at seed and plant levels may be useful for discrimination and verification of varieties, hybridity testing and maintenance of genetic purity at genetic level during seed production and certification program.

\section{Acknowledgement}

I would like to extend my gratitude to Agriculture and Food Security Project (AFSP), NARC for providing the funds during the $\mathrm{PhD}$ research program. Authors would also like to acknowledge the Department of Genetics and Plant Breeding, Agriculture and Forestry University, Rampur, Chitwan for frequent guiding to record the traits. Special thanks go to the technical staffs of Grain Legumes Research Program for helping to conduct the experiment in the station.

\section{References}

1. Arumuganathan K, Earle ED. Nuclear DNA content of some important plan species. Plant Mol. Biol. 1991; 9: 208-218.

2. FAOSTAT. Food and Agricultural Organization, Statistical Databases. 2017.

3. MOAD. Statistical Information of Nepalese Agriculture. Agri-Business Promotion and Statistics Division, Ministry of Agriculture Development Kathmandu, Nepal. 2016

4. Deve F, Munankami R, Bijl B. Advisory services on export development of priority sectors of Nepal: The lentils sectors in Nepal, Export performance and potential. International Trade Centre. UNCTAD/WTO. 2007

5. Gharti DB, Darai R, Subedi S. Grain legumes in Nepal: Present scenario and future prospects. World Journal of Agricultural Research. 2014; 2: 216-222.

6. Erskine W, Sarker A. Lentil. In: H. Corke and C.E. Walker, editors, Encyclopedia of grain sciences. Elsevier, London, UK. 2004; 142-150

7. Malik BA, Tahir M, Haqani AM, Anwar R. Documentation, characterization, and preliminary evaluation of lentil (Lens culinaris) germplasm in Pakistan. Lens News Letter. 1984; 11: 8-11.

8. Ramgiry SR, Paliwal KK, Tomar SK. Variability and correlation of grain yield and other qualitative characters in lentil. Lens News Letter. 1989; 16: 19-21.

9. Sarker A, Erskine W. Utilization of genetic Resources in lentil improvement In: Procedings of the Genetic Resources of Field Crops: Genetic Resources1615-Journal of Pharmacognosy and Phytochemistry Symposium EUCARPIA, Poznam, Poland. 2001; 42.

10. Tullu A, Kusmenoglu I, McPhee KE, Muehlbauer FJ. Characterization of core collection of lentil germplasm for phenology, morphology, seed and straw yields. Genet. Resour. Crop Evol. 2001; 48:143-152.

11. Barulina H. Lentils of the USSR and other counties. Bull Appl Bot Gen Plant Breed. 1930; 40: 225-238.

12. Erskine W, Choudhary MA. Variation between and within lentil landraces from Yemen Arab Republic. Euphytica. 1986; 35: 695-700.

13. Sharma, PC \& Luthra SK, 1987 Geneic divergence in lentil (Lens culinaris Med.), Department of Agricultural Botany, Merrut University, Meerut, India Published in Genet.Agr.41: 1987.

14. Hoffman PC, Armentano LE. Comparison of brewers wet and dried grains and soybean meal as supplements for dairy cattle. Nutr Rep Int. 1988; 38 655-663

15. Erskine W, Adham Y, Holly L. Geographic distribution of variation in quantitative characters in a world lentil collection. Euphytica. 1989; 43: 97 103

16. Erskine W, Williams PC, Nakkoul H. Splitting and dehulling lentil (Lens culinaris): Effects of seed size and different pre-treatments. J. Sci. Food Agric. 1991a; 57: 77-84.
17. Sarker A, Erskine W, Sharma B, Tyagi MC. Inheritance and linkage relationships of flowering time and morphological loci in lentil (Lens culinaris Medikus). J Hered. 1999; 90: 270-275

18. Toklu F, Karako Y, Hakl Y, Bicer E, Randolini T, Kilian AB, et al. Genetic variation among lentil landraces from southeast Turkey Published in Plant Breeding. 2009; 128: 178-186.

19. Tyagi, SD and Khan MH. Studies on genetic variability and interrelationship among the different traits in Microsperma lentil (Lens culinaris Medik). Paper published in Journal of Agricultural Biotechnology and Sustainable Development. 2010; 2: 15-20.

20. Zaccardelli M, Lupo F, Piergiovanni AR, Laghetti G, Sonnante G, Daminat MG, et al. Characterization of Italian lentil (Lens culinaris Medik.) germplasm by agronomic traits, biochemical and molecular markers. Genet Resour Crop Evol. 2012; 59: 727-738.

21. Thakur HK, Bajpai GC. Characterization of lentil germplasm for phenological and. yield characters. Indian J. Pulses Res. 1993; 6: 89-91.

22. Singh JP, Singh IS. Evaluation of lentil germplasm for plant type, initia flowering. and.disease resistance. LENS. 1994; 21: 5-7.

23. Ladizinsky $\mathrm{G}$. The genetics of several morphological traits in the lentil. Journa of Heredity. 1979; 70: 135-137.

24. Mishra SK, Kumar R, Kumar Y. Inheritance of foliage colour in lentil. Abstract National Symposium on Pulses for Sustainable Agriculture and Nutritional Security, New Delhi. 2001.

25. Hoque ME, Mishra SK, Kumar Y, Kumar R, Tomar SMS, Sharma E. Inheritance and linkage of leaf colour and plant pubescence in lentil. Indian J Genet. 2002; 62: 140-142.

26. Sharma B, Emami MK. Discovery of new gene causing dark green cotyledons and pathway of pigment synthesis in lentil (Lens culinaris Medik.). Euphytica. 2002; 124: 333-353.

27. Bakhsh A, Iqbal MS, Cheema NM. Inheritance of morphological characters associated with plant and dried seeds in lentil (Lens culinaris Medik.). Pakistan Journal of Botany. 2013; 45: 1497-1502.

28. Singh M, Bisht IS, Dutta M, Kumar K, Kumar S, Bansal KC. Genetic studies in morpho-phenological traits in lentil (Lens culinaris Medikus) wide crosses. Journal of Genetics. 2014; 93:561-566.

29. Dixit GP, Katiyar PK, Singh BB. Characterization of lentil (Lens culinaris Medik.) varieties based on morphological traits. Journal of Food Legumes. 2011; 24: 194-197.

30. Chaudhary, R.G., Saxena, D.R. Dhar V. and Singh, R.K. 2010. Prevalence of wilt root rots and their associated pathogens at reproductive phase in lentil. Phytopathol. Plant Prot. 43:996-1000

31. Baraimer A, Izquidero J. Pathogenicity test for Fusarium oxysporum on lenti lines. LENS Newsletter. 1977; 4: 29-31

32. Hawtin GC, Singh KB, Saxena MC. Some Recent Development in the Understanding and Improvement of Cicer and Lens. In: Summerfield RJ, Bunting $\mathrm{AH}$ (eds.), Advances in Legumes Science. Proceedings of the International Legume Conference, Kew, 31 July-4 August 1978, Royal Botanic Garden, Kew, the Missouri Botanical Garden, and the University of Reading, UK.1980; 613-623.

33. Muehlbauer FJ, Cubero JI, Summerfield RJ. Lentil (Lens culinaris Medic.) In: Summerfield RJ, Roberts EH (eds.), Grain Legume Crops. Collins. 1985; 266-311.

34. Kays D. Food Legumes. Tropical development and research institute (TPI). TPI Crop and Product Digest No. 1979; 3: 48-71. 